\title{
Vitellaria paradoxa Wood as a Potential Source of Dietary Fibre
}

\author{
Abdullahi Alanamu ABDULRAHAMAN*, Oluwaseyi \\ Doyinsola AKANBI, Felix Ayotunde OLADELE \\ University of Ilorin, Faculty of Science, Department of Plant Biology, P.M.B 1515, Ilorin, Kwara \\ State,Nigeria; abdulrabamanaa@unilorin.edu.ng ( ${ }^{*}$ corresponding author)
}

\begin{abstract}
In the tropical developing countries, diseases such as diabetes, tuberculosis, cancer, obesity have been a continuous cause of mortality. In recent times, nutrition experts have come up with new ideas for food recipe, with a view to improving human health. One of these ideas is to enhance dietary fibre content to improve food digestibility and bowel movement. In this study the effect of the processed insoluble wood fibres on the blood system of albino rats was studied by feeding the rats with the processed Vitellaria paradoxa wood fibres added to the animals' normal diet for a period of 28 days across four treatments namely the control, $10 \%, 15 \%$ and $20 \%$ processed wood fibres.. These cellulosic materials incorporated into normal diet of the albino rats did not cause a reduction in the live weight of the experimental animals. A paired sample t-test conducted on the two sets of data indicated no significant difference $(\mathrm{P}=0.8390>0.05)$ in the mean initial and final haematocrit. Therefore the wood fibre supplemented diet did not have had any deleterious effects on the quality and quantity of the rats' blood. Thus there is also a possibility that the cellulosic fibres did not reduce the plasma cholesterol level concentrations of the rats. Processed wood was also used in baking bread. The addition of cellulosic fibres did not negatively affect the physical, chemical and baking properties of bread, but it prolonged the shelf-life of the bread.
\end{abstract}

Keywords: food recipes, haematological analysis, insoluble dietary fibres, nutrition, nutritional diseases, wood of Vitellaria paradoxa

\section{Introduction}

A living organism is the product of nutrition and nutrition is the science of food values (Begum, 1991). Nutrition is relatively a new science and the effect of food on our body is explained in nutrition. In other words, nutrition is defined as food that work in the body but in a broader sense, it is defined as the combination of processes by which the living organism receives and utilizes the material necessary for the maintenance of its functions and for the growth and renewal of its components. When all essential nutrients are present in a correct proportion as required by our body, it is called optimum nutrition or adequate nutrition. Signs of good nutrition include clear complexion, fresh skin and correct posture, good inquisitive and alert eyes, confident deeds, pleasing personality, correct height and weight for the age.

Since diseases such as obesity is mainly caused by excessive calorie consumption, as such, foods with low calorific values and high dietary fibre contents should be consumed. Reduction in high calorie foods and diet will result in the maintenance and restoration of good nutrition along with gradual reduction in body weight. Hence, high fibre and low calorific foods must be included in dietary pattern. Of such high fibre foods is the use of wood fibres (dietary fibres) as food additives since dietary fibres aim at providing a sense of satisfaction and well-being to its consumers.

The plant kingdom represents a vast emporium of untapped medicinal potentialities and this had led to the re- surgence of interests in ethnomedicine, ethnobotany, plant anatomy and taxonomy and ethnopharmacology (Fadeyi et al., 1998). In the areas of plant anatomy especially wood anatomy, researches propose the consumption or use of wood fibres as food additives and this can be linked to an hypothesis relating several diseases common in affluent societies to lack of dietary fibres. And as a result, the concept of taking dietary fibres to improve food digestibility and bowel movement has generated some interests in medical circles. There is an increased interest in alternative therapies globally (WHO, 2003) and a constituent increase in the use of plant derived products as they are convenient alternatives or are complementary to the use of orthodox or synthetic drugs. This is due to adverse side effects of conventional drugs and to the drift towards consuming natural products as opposed to synthetic ones as well as the increasing awareness of the beneficial effects of natural products (Duke, 1990).

Fibres have been found to considerably modulate hepatic, blood and intestinal lipids and lipoprotein profiles (Vahouny, 1982). Therefore the increasing awareness in nutritional therapy towards avoiding the various diseases associated with overweight (Damon, 1979). The concept of taking regular exercise and avoidance of high calorie foods in order to keep the body weight down has gained some considerable popularity in the last decade (Oladele, 1991). Dietary fibre is a major constituent of plant food and it is important in nutrition and health and in the prevention of cardiovascular diseases, cancer, diabetes and 
obesity (Spiller, 2005; Sungso and Diche, 2001). Dietary fibre has been defined as the plant polysaccharide and lignin which are resistant to hydrolysis by the digestive enzymes of man (Trowell, 1976). Dietary fibre can also be referred to as food materials particularly of plant origin that are not hydrolyzed by enzymes secreted by the human digestive tract but that may be digested by microflora in the gut (Anonymous, 2001).

Dietary fibres as indigestible part of plant food guard against heart diseases, certain cancers, Type 2 diabetes, obesity and premature death. It also get low the cholesterol, improves blood sugar levels, reduces blood pressure; promote weight loss and keep the body regular at all times. Dietary fibre consists of two main components: soluble and insoluble fibres. The soluble fibre is that which is readily fermented in the colon into gases and physiologically active byproducts while the insoluble fibre is that which is metabolically inert, absorbing water as it moves through the digestive system and hence making defecation easy (Anonymous, 2005). Dietary fibres act by changing the nature of the contents of the gastrointestinal tract, and by changing how other nutrients and chemicals are absorbed (Eastwood and Kritchevsky, 2005). Chemically, dietary fibres consist of non-starch polysaccharides such as cellulose and many other plant components like resistant dextrins, inulin, lignin, chitins, beta-glucans and oligosaccharides (Anonymous, 2005). Dietary fibre is found in plants although in varying degrees. Fibre-rich plants can be eaten raw or can be alternatively used to make supplements (i.e. food additives) and fibre-rich processed foods. Dietary fibre has been used as a collective term for a complex mixture of substances with different chemical and physical properties which exert different types of physiological effects and are therefore recognized by the fact that they are either nutritionally useful or have the potential for consumption . Increase in dietary fibre intake, will increase post-meal satiety and decrease subsequent hunger. It also increases body weight loss and greatly suppress energy intake in obese people (Howarth et al., 2001). One of the possible cheapest means of dietary fibre administration is to add processed fibres to regular foods (Damon, 1979).

Vitellaria paradoxa commonly known as shea tree, shea butter tree, shi tree, vitellaria or karité, is a tree of the Sapotaceae family indigenous to Africa, occurring in Mali, Cameroon, Congo, Côte d'Ivoire, Ghana, Guinea, Togo, Nigeria, Senegal, Sudan, Burkina Faso and Uganda. The shea fruit consists of a thin, tart, nutritious pulp that surrounds a relatively large, oil-rich seed from which shea butter is extracted. The shea tree has been claimed to have potential to improve nutrition, boost food supply in the "annual hungry season" (Masters et al., 2011), foster rural development and support sustainable land care (National Research Council, 2006). The shea butter tree is a wild plant species thriving abundantly in the Guinea and Derived savannas' woodlands of Nigeria, even on poor soil was used in this study. Meanwhile, species such as $V \cdot$ para- doxa, Milicia excels, Anogeissus leiocarpus and others were earlier identified by AbdulRahaman et al. (2009) as most exploited species as firewoods in 6 Local Government Areas (Asa, Ilorin-East, Ilorin-South, Ilorin-West and Moro) of Kwara State, Nigeria. Therefore drastic efforts must be taken to stop this problem. One of these efforts may be using the plant, V.paradoxa as dietary fibre in baking foods. The tree is medicinal and it is widely used in different areas of medicine. Lipid in shea butter is digested easely and serves as a better source of energy for protein sparing than carbohydrates as well as sources of essential fatty acids. The wood fibres from $V$. paradoxa are potential dietary fibres and considering its wide distribution, it will serves as a cheap source of fibres.

Soluble fibres have been added to some baked food for human consumption especially in the United States of America (Anonymous, 2001); insoluble fibres have not been exploited for the same purpose. Therefore, this study is a preliminary one to determine the potentiality of $V$.paradoxa wood, which is an insoluble fibre, as a source of dietary fibre, to examining the blood and live weight responses of laboratory animals fed on diets containing the wood fibres and also to bake and assess the physical characteristics of laboratory-baked loaves of bread from fibre-supplemented wheat flour.

\section{Materials and methods}

\section{Study materials}

Wood of sheanut tree, Vitellaria paradoxa was used as a source of insoluble dietary wood fibre. Its wood is also a good source of energy as firewood. Sixteen laboratory animals, albino rats of about eight weeks old were purchased from Biochemistry Department of the University of Ilorin, Ilorin, Nigeria.

\section{Wood anatomical studies}

From freshly collected wood discs samples, a shorter wood disc of about $4 \mathrm{~cm}$ were cut by means of a hand saw. The circumference of the latter disc was divided into four equal sectors by drawing a cross sign with its origin at the centre. Four blocks of wood each of about $4 \times 2 \times 2$ $\mathrm{cm}$ were cut out from the sectors and immediately fixed in formal-acetic-alcohol (FAA) contained in a labelled specimen bottle (Jane, 1970). Thin transverse sections (TS) and tangential longitudinal sections (TLS) of about 10 $\mu \mathrm{m}$ were cut from the wood blocks using a freezing stage microtome.

\section{Tissue maceration}

Tissue maceration was done by boiling a small block of wood for $5 \mathrm{~min}$ in concentrated nitric acid $\left(\mathrm{HNO}_{3}\right)$ to which a few crystals of potassium chlorate was added (Ademiluyi and Okeke, 1975). The softened tissue was washed in several changes of water, transferred onto a microscopic slide and teased out by tapping gently with a 
146

glass rod. Staining was done in safranin and mounting in glycerine.

\section{Feeding trials of albino rats with wood fibres as a supplement}

Sixteen albino rats of about eight weeks old were obtained along with their normal compounded feed. The rats were marked for the purpose of identification and were acclimatized for two weeks in wooden cages with access to their normal feed and water. After two weeks, the rats were divided into four diet groups; each containing two males and two females. The initial live weight of all the rats was determined weekly in grams with the aid of a weighing balance. The first group which was fed on normal diet without fibre served as control. The second group was placed on $10 \%$ wood fibre mixed with $90 \%$ normal feed; the third on $15 \%$ wood fibre mixed with $85 \%$ normal feed and the fourth on $20 \%$ wood fibre mixed with $80 \%$ normal feed. Each of the groups was supplied with the same quantity of feed in powdered form and water for a period of four weeks.

\section{Diet's preference index}

The percentage feed intake per week was achieved as the diet's preference index for each of the four treatment levels. This was determined as a percentage using formula of Ogunkunle et al. (2003):

$\mathrm{T}_{\mathrm{c}}-\mathrm{T}_{1} / \mathrm{T}_{\mathrm{c}} \times 100$

Where:

$\mathrm{T}_{\mathrm{c}}=$ cumulative weight of rat meal supplied to a group in one week;

$\mathrm{T}_{1}=$ left over of the meal at the end of the week.

\section{Live weight of the rats}

The live weight of each albino rats in each feeding group was determined by weighing them weekly, basis for the period of four weeks.

\section{Blood Packed Cell Volume (PCV)}

The percentage blood Packed Cell Volume (PCV) of each rat was determined with the aid of a heamatocrit centrifuge (Barrelet, 2004). Their percentage blood PCV was observed at the beginning of the first week and at the end of the fourth weeks of feeding them with diets containing wood fibres.

\section{Baking of bread (fortified and non-fortified)}

About $1 \mathrm{~kg}$ of the commercial wheat flour was obtained and flour dough was prepared from it. Four different kinds of dough were prepared, one control and three experimental. The stem of the plant was debarked and the woody stem pulverized. Each of the experimental dough, $0.25 \mathrm{~g}, 0.5 \mathrm{~g}$ and $1.0 \mathrm{~g}$ of the pulverized wood fibres was added and mixed thoroughly with $50 \mathrm{~g}$ of wheat flour before dough preparation. Each of the four set-ups was pre- pared in four replicates and then placed in oven at $120^{\circ} \mathrm{C}$ for about 1 hour (Ogunkunle et al., 2003).

\section{Assessment of the loaves of bread}

The breads were assessed through questionnaires administered to some selected individuals on the acceptability of their colour, texture and flavour. The selected people commented on the acceptability or/and suitability of bread. Mean dimensional characteristics such as mean weight $(\mathrm{g})$, mean height $(\mathrm{cm})$, mean area $\left(\mathrm{cm}^{2}\right)$ and mean volume $\left(\mathrm{cm}^{3}\right)$ of breads were also determined. Weight of a loaf of bread was determined using a weighing balance and the height determined by inserting a long needle into the loaf and determining the extent on a metre rule. The shelf lives of the four categories of breads were determined by exposing the loaves to laboratory conditions and the number of days before any noticeable fungal infestation was achieved.

\section{Statistical analysis}

A paired-sample T-test was conducted on the initial and final haematocrit values for all the rats. The data from albino rat feeding trail was analyzed using one-way ANOVA at three different levels (Bailey, 1995).

\section{Results and discussion}

\section{Wood structure of V.paradoxa}

The wood is brownish yellow in colour and diffuse porous. The fibres are relatively long with thin cell wall and moderate lumina. The fibres are elongated and have simple pit with pointed ends. The vessel members are elongated and cylindrical in nature with fairly thin cell wall, bordered pit and wide lumina. The tracheids are also elongated, have narrow cells each with tape ring pointed end. The rays are uniseriate and there are more tracheids and fibres present, compared to vessel members (Fig. 1 and Fig. 2).

The fibres are sufficiently thin-walled with a relative length of $9.23 \mu \mathrm{m}$ and mean length of $200 \mu \mathrm{m}$ (Tab. 1). The fibres are not as flexible as indicated by the low coef-

Tab. 1. Several dimensional characteristics of Vitellaria paradoxa wood

\begin{tabular}{ccc}
\hline Mean values & $\begin{array}{c}\text { Fibre } \\
\text { dimensions } \\
(\mu \mathrm{m})\end{array}$ & $\begin{array}{c}\text { Vessel } \\
\text { dimensions } \\
(\mu \mathrm{m})\end{array}$ \\
\hline Length $(\mu \mathrm{m})$ & $200.00 \pm 0.05$ & - \\
\hline Diameter $(\mu \mathrm{m})$ & $21.72 \pm 0.43$ & $14.93 \pm 0.05$ \\
\hline Fibre lumen width $(\mu \mathrm{m})$ & $10.6 \pm 0.05$ & $18.55 \pm 3.55$ \\
\hline Wall thickness $(\mu \mathrm{m})$ & $5.01 \pm 0.05$ & $5.96 \pm 0.05$ \\
$\begin{array}{c}\text { Relative fibre length }=\text { Fibre } \\
\text { length/ Fibre diameter }(\mu \mathrm{m})\end{array}$ & $9.23 \pm 0.16$ & - \\
\hline $\begin{array}{c}\text { Coefficient of flexibility }=\text { Fibre } \\
\text { lumen width/ Fibre diameter }\end{array}$ & $0.49 \pm 0.01$ & - \\
\hline
\end{tabular}




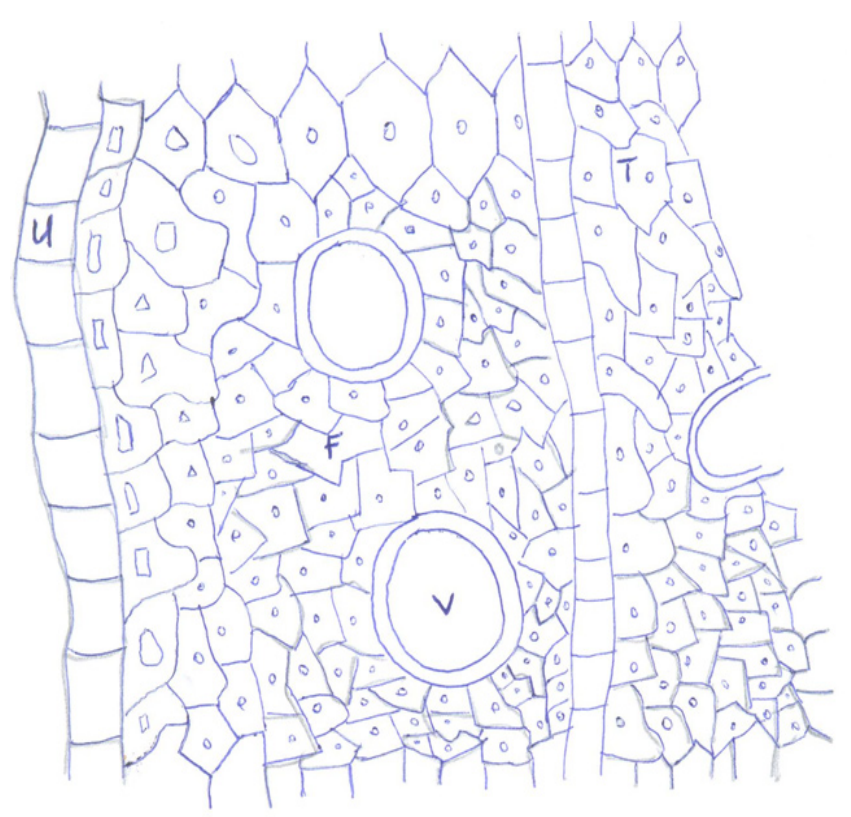

Fig. 1. Transverse Section (TS) of Vitellaria paradoxa wood

$\mathrm{U}=$ Uniseriate ray; $\mathrm{F}=$ Fibre $\mathrm{V}=$ Vessel $; \mathrm{T}=$ Tracheid $; \mathrm{B}=$ Bordered pit; $S=$ Simple pit $\times 40$

ficient of flexibility (i.e. 0.49). Furthermore the vessels are fairly thick walled and cylindrical in nature and so the vessels would not collapse readily and blend with the fibres during the mechanical processing.

Responses of albino rats to fibre supplemented diets

The behavioural and biological responses of albino rats to four feeding trials are displayed in Tab. 2 and Tab. 3. The preference index of the rats' diet increased with increasing wood fibre content in their meal.

Although the preference index of all the rats increased throughout the period of feeding with increasing wood fibre supplements in their meal, the statistics between their means show a significant difference between them, $\mathrm{P}$ being $<0.05$. This implies that the fibre-free diet is the most preferred to the rats and the other treatment levels were not that acceptable to them. The mean live weight of all the rats increased throughout the four weeks of experiment (Tab. 2). At the end of the first week, the lowest mean weight of $134.50 \mathrm{~g}$ was recorded in the rats fed at $20 \%$ fibre level while the highest, 140.75 was in those fed at $15 \%$ fibre level. But at the end of the fourth week, the lowest (158.25 g) was recorded at $15 \%$ level and the highest mean weight $(179.75 \mathrm{~g})$ recorded was in the control group. The results of the ANOVA conducted on the live weights responses of the rats did not show a significant difference (Tab. 3) at the three factor levels namely, treatments, weekly responses and replication at $\mathrm{P}>0.05$. Therefore it can be conclude that the fibre added to the rats' meal does not have any effect on the live weights of the rats.

Osilesi et al. (1992) observed that cellulose (an insoluble fibre) did not determine lower plasma cholesterol nor did it bind bile acids in vitro or in vivo. Findings from

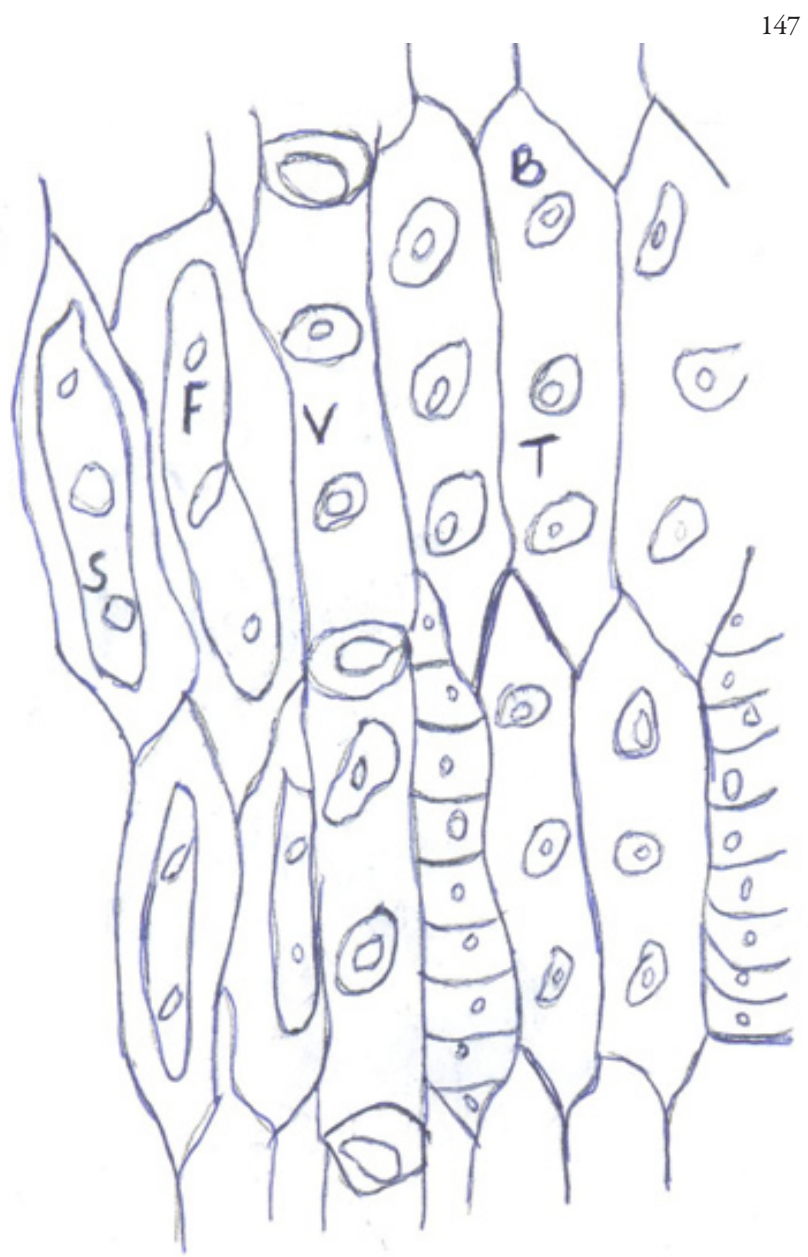

Fig. 2. Tangential Longitudinal Section (TLS) of Vitellaria paradoxa wood $\times 40$

$\mathrm{F}=$ Fibre; $\mathrm{V}=$ Vessel; $\mathrm{T}=$ Tracheid; $\mathrm{B}=$ Bordered pit; $\mathrm{S}=$ Simple pit $\times 40$

the present research work corroborate this observation. A paired sample T-test conducted on the two sets of data indicated no significant difference $(\mathrm{P}=0.8390>0.05)$ in the mean difference between mean initial and final haematocrit (Tab. 2). The confidence interval is between $43 \%$ and $45 \%$ which is within the acceptable standard. The haematocrit or packed cell volume (PCV) or erythrocyte volume fraction $(\mathrm{EVF})$ is the percentage of blood volume that is occupied by red blood cells. It is normally about $45 \%$ for men and $40 \%$ for women (Purves et al., 2004). It is considered an integral part of a person's complete blood count results, along with haemoglobin concentration, white blood cell count, and platelet count. In mammals, haematocrit is independent of body size. Thus the PCV figures obtained are positive signs of good health. This is because condition of elevated or lower figure of EVF or PCV indicates danger. In cases of dengue fever, a high haematocrit is a danger sign of an increased risk of dengue shock syndrome and a Lower haematocrit can imply significant haemorrhage. Therefore the wood fibre supplemented diet could not have had any deleterious effects on the quality and quantity of the rats' blood. 
148

Characteristics of laboratory-baked bread

The flavours of both the control and the experimental loaves of bread was $100 \%$ acceptable to all the respondents (Tab. 4).

The colour of the loaves of bread ranged from light brown with cream tint in the control to pale brown in the $1.00 \mathrm{~g}$ fibred loaves (Tab. 4). Of all the 30 respondents whose opinions on assessment was sought, 13 (i.e. 45\%) preferred the light brown colour of the $0.25 \mathrm{~g}$ fibre loaves and pale chocolate brown colour of the $0.50 \mathrm{~g}$ fibred loaves while the remaining, $55 \%$ preferred the cream-tinted light brown colour of the control loaves. The flavours of both the control and experimental loaves were $100 \%$ acceptable to all respondents (Tab. 4). These results show that the colour and flavour of fibre-supplement bread were accepted to bread consumers.

The control loaves have the shortest shelf life of 4 days and a shelf life of 5 days each was recorded for $0.5 \mathrm{~g}$ and $1.0 \mathrm{~g}$ of fibred loaves. However, a shelf life of 6 days was recorded for the $0.25 \mathrm{~g}$ fibred loaves. This result therefore

Tab. 2. Blood and live weight responses of albino rats to four feeding trial diets over a period of four weeks

\begin{tabular}{|c|c|c|c|c|c|c|c|}
\hline Feeding trial & Parameter & Initial value & First week & Second week & Third week & Fourth week & Mean \\
\hline \multirow{4}{*}{$\begin{array}{c}\text { Control } \\
(100 \% \text { normal diet })\end{array}$} & $\begin{array}{l}\text { Preference } \\
\text { index }(\%)\end{array}$ & & 71.43 & 69.64 & 64.12 & 66.43 & 67.91 \\
\hline & Weight (g) & 119.25 & 137.75 & 153.00 & 166.00 & 179.75 & \\
\hline & $\%$ weight increase & & & & & 50.73 & \\
\hline & $\operatorname{PCV}(\%)$ & 39.5 & & & & 41.5 & \\
\hline \multirow{5}{*}{$10 \%$ wood fibre } & $\begin{array}{l}\text { Preference } \\
\text { index }(\%)\end{array}$ & & 69.29 & 78.57 & 71.61 & 74.82 & 73.57 \\
\hline & Weight (g) & 120 & 137.75 & 145.5 & 159.75 & 158.75 & \\
\hline & $\%$ weight increase & & & & & 32.29 & \\
\hline & $\%$ weight reduction & & & & & 63.65 & \\
\hline & PCV $(\%)$ & 43.25 & & & & 42.75 & \\
\hline \multirow{5}{*}{$15 \%$ wood fibre } & $\begin{array}{l}\text { Preference } \\
\text { index }(\%)\end{array}$ & & 73.39 & 78.04 & 73.57 & 73.93 & 74.73 \\
\hline & Weight (g) & 123.75 & 140.75 & 151.50 & 162.25 & 158.25 & \\
\hline & \% weight increase & & & & & 27.88 & \\
\hline & $\%$ weight reduction & & & & & 54.96 & \\
\hline & PCV $(\%)$ & 46.25 & & & & 45.25 & \\
\hline \multirow{5}{*}{$20 \%$ wood fibre } & $\begin{array}{l}\text { Preference } \\
\text { index }(\%)\end{array}$ & & 69.12 & 78.39 & 79.82 & 78.75 & 76.52 \\
\hline & Weight (g) & 112.75 & 134.50 & 144.75 & 176.75 & 172.75 & \\
\hline & $\%$ weight increase & & & & & 53.22 & \\
\hline & $\%$ weight reduction & & & & & 104.91 & \\
\hline & $\operatorname{PCV}(\%)$ & 47 & & & & 47.5 & \\
\hline
\end{tabular}

Tab. 3. The results of ANOVA conducted on the mean live weights of the rats

\begin{tabular}{cccccc}
\hline Sources of variation & Degrees of freedom & Sums of squares & Mean Squares & F & P-values \\
\hline Treatment & 3 & 734.4219 & 244.8073 & 2.30 & 0.0877 \\
Weeks & 3 & 9885.9219 & 3295.3073 & 30.95 & 0.0000 \\
Replications & 3 & 91.5469 & 30.5156 & 0.29 & 0.8348 \\
Error & 54 & 5749.0938 & 106.4647 & - & - \\
Total & 63 & 16460.985 & - & - & - \\
\hline
\end{tabular}

Tab. 4. Several qualitative and quantitative characteristics of the baked bread

\begin{tabular}{|c|c|c|c|c|c|c|c|}
\hline Type of loaf & Colour & Flavour & $\begin{array}{c}\text { Mean weight } \\
\text { (g) }\end{array}$ & $\begin{array}{c}\text { Mean height } \\
(\mathrm{cm})\end{array}$ & $\begin{array}{l}\text { Mean area } \\
\left(\mathrm{cm}^{2}\right)\end{array}$ & $\begin{array}{l}\text { Mean volume } \\
\left(\mathrm{cm}^{3}\right)\end{array}$ & $\begin{array}{l}\text { Shelf life } \\
\text { (days) }\end{array}$ \\
\hline $\begin{array}{l}0 \mathrm{~g} \text { fibre content } \\
(\text { Control })\end{array}$ & $\begin{array}{l}\text { Light brown } \\
\text { with cream tint }\end{array}$ & Acceptable & 471.50 & 9.53 & 264.57 & 2521.35 & 4 \\
\hline $0.25 \mathrm{~g}$ fibre content & Light brown & Acceptable & 612.00 & 9.75 & 278.20 & 2712.45 & 6 \\
\hline $0.5 \mathrm{~g}$ fibre content & $\begin{array}{c}\text { Pale chocolate } \\
\text { brown }\end{array}$ & Acceptable & 623.75 & 9.63 & 269.52 & 2595.48 & 5 \\
\hline $1.0 \mathrm{~g}$ fibre content & Pale brown & Acceptable & 696.75 & 9.8 & 270.35 & 2649.43 & 5 \\
\hline
\end{tabular}


shows that fibred loaves of bread can effectively compare with those commercially available loaves.

From the dimensional characteristics, it can be observed that the $1.0 \mathrm{~g}$ fibre loaf was the heaviest and the highest with $696.75 \mathrm{~g}$ and $9.80 \mathrm{~cm}$ respectively. The control loaves have the lightest mean weight of $471.5 \mathrm{~g}$ and the lowest mean height of $9.53 \mathrm{~cm}$ and occupying the lowest mean area of $264.57 \mathrm{~cm}^{2}$. The mean volume of the bread loaves ranged between $2521.35 \mathrm{~cm}^{3}$ in the control to $2649.43 \mathrm{~cm}^{3}$ in the $0.25 \mathrm{~g}$ fibred loaves. Therefore, experimental loaves are generally of larger sizes than the control. From these results and the ANOVA conducted, it can be inferred that the addition of cellulose fibres to wheat flour dough does not adversely affect its baking properties but instead, it enhances and improves the quality, size and shelf-life of the loaves.

\section{Conclusions}

The fibres of $V$.paradoxa are potential insoluble dietary fibre with the prospect for human consumption. These cellulosic materials incorporated into normal diet of the albino rats did not cause a reduction in the live weight of the experimental animals. Therefore, there is a possibility that the cellulosic fibres did not reduce the hepatic or reduce the plasma cholesterol level concentrations of the rats. Also, the addition of cellulosic fibres does not negatively affect the physical, chemical and baking properties of bread. Instead the fibre prolong the shelf-life of the breads than those of control ones.

\section{References}

AbdulRahaman AA, Ihaza OC, Oladele FA (2009). A survey of some economic trees and their exploitation in Irepodun Local Government Area of Kwara State, Nigeria. Biol Environ Sci J Tropics 6(1):57-60.

Ademiluyi EO, Okeke RE (1975). Studies on specific gravity of fibre characteristics of Gmelina arborea in some Nigeria plantations. Nig J Sci 13:231-238.

Anonymous (2001). Information Statement on Dietary Fibre. Institute of Food Sciences and Technology (IFST), United Kingdom.

Anonymous (2005). Dietary, functional and total fibre. Food and Nutrition Board. http://www.nal.usda.gov/fnic// DRIEnergy/339-421

Bailey NTJ (1995). Statistical Methods in Biology. Cambridge University Press, Cambridge, 255 p.

Barrelet A (2004). Laboratory tests in equine practice Part 2: Haematological analyses. UK Vet 9(8):13-23.

Begum MR (1991). A textbook of food, nutrition and dietetics. Second Revised Edition. Sterling Publishers Pvt Ltd. New Delhi.
Damon GE (1979). A primer of proteins and fibres, p. 384388. In: The new book of popular science. Grolier Limited, Canada.

Duke JA (1990). Promising phytomedicinals, p. 491-498. In: Janick J, Simon JE (Eds.). Advances in New Crops. Timber Press.

Eastwood M, Kritchevsky D (2005). Dietary fibre: how did we get where we are? Ann Rev Nutrit 25:1-8.

Fadeyi MO, Adeoye AO, Olowokudejo JD (1998). Epidermal and phytochemical studies in the genus Boerhavia (Linn.) (Nyctaginaceae) in Nigeria. Internat J Crude Drug Res 27:178-184.

Howarth NC, Saltzman E, Robert SB (2001). Dietary fibre and weight regulation. Nutrit Rev 59(5):129-139.

Jane FW (1970). The Structure of Wood. $2^{\text {nd }}$ ed. Reviewed by Wilson $\mathrm{K}$ and White DJB. Adam and Charles, London. 3-69 p.

Masters ET, Yidana JA, Lovett PN (2011). Reinforcing sound management through trade: shea tree products in Africa. http://www.fao.org/docrep/008/y5918e/y5918e11.htm.

National Research Council (2006). Shea. Lost Crops of Africa: Volume II: Vegetables. Lost Crops of Africa. 2. National Academies Press. http://books.nap.edu/openbook. php?record_id $=11763$ \&page $=303$.

Ogunkunle ATJ, Afolabi OO, Oladele FA (2003). Structure and potential of Gmelina arborea wood as a source of dietary fibre in foods. Internat J Biol Physical Sci 2:41-48.

Oladele FA (1991). Essentials and applications of wood anatomy. J. O. Olatiregun (Nig). Company, Ilorin.

Osilesi I, McCarthy P, Adebawo O, Olowokere J (1992). Hyperlipidemic effect of soluble and insoluble dietary fibres in Streptozocin-induced diabetic rats. Biosci Res Communic 4(1):65-73.

Purves WK, Sadava D., Orians GH, Heller HC (2004). Life: The Science of Biology (7th ed.). Sunderland, Mass: Sinauer Associates, $954 \mathrm{p}$.

Spiller GA (2005). Dietary fibre in the prevention and treatment of diseases. In: Handbook of Dietary Fibre in Human Nutrition. Boca Raton, CRC Press, Washington DC.

Sungso CS, Diche ML (2001). Handbook of dietary fibre. Marcel Dekker, Inc.

Trowell H (1976). Definition of dietary fibre and hypothesis that it is a protective factor in certain diseases. AMJ Clinic Nutrit 29:417-427.

Vahouny GV (1982). Dietary fibre, lipid metabolism and atherosclerosis. Federal Proc 41:2801-1906.

WHO (2003). WHO Guidelines on Agricultural and Collection Practices (GACP) for Medical Plants. www.leslieback.com. 